College of Veterinary Medicine,

Sudan University of Science and Technology,

P.O.Box. 204 Khartoum North, Sudan.

\title{
METHOD FOR REDUCING CONTAMINATION OF INDIGENOUS CATTLE CARCASSES DURING SLAUGHTERING
}

(With 2 Tables)

By

\section{M.A. ABDALLA; SIHAM E. SULIMAN and A.O. BAKHIET}

(Received at 10/2/2010)

\section{SUMMARY}

The bacteriological study was carried out to evaluate the degree of contamination in indigenous cattle carcasses in slaughterhouse, in Khartoum State, during April 2009 - June 2009. For the total viable counts (TVCs), 768 swab samples were collected from 32 carcasses. Sterilization by hot tap water $\left(82{ }^{\circ} \mathrm{C}\right)$ to worker's hands and their knives was applied in all slaughtering operations. The mean total viable count (TVCs) after skinning, evisceration and washing operations at brisket site were $1.4 \pm 0.12,1.5 \pm 0.09$ and $1.5 \pm 0.06 \log _{10}$ CFU (colony forming unit) $/ \mathrm{cm}^{2}$, in the shoulder site were, $1.3 \pm 0.09,1.2 \pm 0.11$ and $1.1 \pm 0.05 \log _{10} \mathrm{CFU} / \mathrm{cm}^{2}$, in the neck site were $1.7 \pm 0.05,1.4 \pm 0.06$ and $1.6 \pm 0.06 \log _{10} \mathrm{CFU} / \mathrm{cm}^{2}$ whereas in the rump site the TVCs in these operations were $1.4 \pm 0.06,1.1 \pm 0.07$, and $1.2 \pm 0.10 \log _{10}$ $\mathrm{CFU} / \mathrm{cm}^{2}$, respectively with statistically significant difference $(\mathrm{P}<0.05)$. Also there were reduction in TVCs of worker's hands and their knives with statistically significant difference $(\mathrm{P}<0.05)$.

Key words: Cattle carcasses, microbial contamination, slaughterhouse, total viable count.

\section{INTRODUCTION}

Microbial contamination of animal carcasses during slaughtering is an unavoidable problem in the conversion of live animals to meat for consumption (Dickson and Anderson 1991). Carcass dressing and evisceration processes constitute critical points in the microbial contamination of muscle for which corrective measures need to be implemented (Bacon et al., 2000; Cutter et al., 2000; Abdalla et al., 
2009a; Abdalla et al., 2009b). Fecal matter was a major source of contamination and could reach carcasses through direct deposition, as well as by indirect contact through contamination with clean carcasses, equipment, workers, installations and air (Borch and Arinder, 2002; Abdalla et al., 2009a; Abdalla et al., 2009b). Cattle slaughter operations, such as bleeding, dressing, and evisceration, may expose sterile muscle to microbiological contaminants that are present on the skin, the digestive tract, and in the environment (Gill and Jones, 1999; Bacon et al., 2000; Abdalla et al., 2009a; Abdalla et al., 2009b). It has been demonstrated that the workers and their slaughter instruments could spread contamination into the internal organs of beef cattle. Dickson and Anderson (1992) isolated Salmonella spp. and Escherichia coli from the hands of workers. The presence of bacteria of potential public health significance was explained by Dolye (1991) and Biss and Hathaway (1995) during slaughtering operations. There were significance increases in total bacterial counts at skinning points than that at washing operations and also dirty worker's hands, clothes and equipments of the slaughterhouse acted as intermediate sources of contamination of meat (Gill, 1998; Gilmour et al., 2004; Abdelsadig, 2006; Abdalla et al., 2009a; Abdalla et al., 2009b). Ali (2007) recorded high contamination level on rump sites during skinning. Cattle and their environment were represented important sources of pathogenic E. coli (Hancock et al., 1998; Elder et al., 2000).

There were many studies and also many countries round the world adapted laws for hygienic practice in slaughterhouse (Hess and lott 1970; Dixon et al., 1991; Schutz, 1991). The reduction of pathogens can also be obtained by adopting slaughtering practice such as closing of rectum. Gerats (1990) approved association between slaughter practice and hygienic practice of the workers. The washing of hands and disinfestations with hot water rarely take place, and both hygienic disposition and easy access to hygienic facilities were important for hygienic behavior in slaughterhouse (Gerats et al., 1982; Tazelaar 1987; Stolle and Reuter 1989; Abdalla et al., 2009a; Abdalla et al., 2009b). A variety of methods has been developed to reduce the levels of contaminating bacteria on carcasses, although most of the current methods focus on washing and sanitizing procedures (Dickson and Anderson. 1992).

The goal of this study were to evaluate the effectiveness of using washing of hands and knives in reducing microorganisms, on beef carcasses during different steps of slaughtering operations 


\section{MATERIALS and METHODS}

The study was conducted for a period of three months, from April to June 2009, at Sabloga Slaughterhouse in Khartoum city. The carcasses were selected randomly.

The selected carcasses, workers hands and knives were sampled before (control) and after treatment in which workers hands and knives were sterilized under hot tap water $\left(82^{\circ} \mathrm{C}\right)$ in between various operations of slaughtering according to (Gill et al., 1998).

A total of 768 samples were taken from four separate sites namely the brisket, shoulder, neck and rump on eight replicated times (32 carcasses), before control and after treatment, at skinning, evisceration and washing respectively. Carcass sites were sampled by the swab-technique an area of $100 \mathrm{~cm}^{2}$ was marked with a sterile frame $(10 \mathrm{~cm} \times 10 \mathrm{~cm})$ for each site on the carcass. Also $60 \mathrm{swab}$ samples were taken from each worker hands and the knives used for different slaughtering operations. The total viable counts were done according to Barrow and Feltham (1993).

The data were analyzed using SPSS software (Statistical Package for the Social Sciences, version 11.5, SSPS Inc, and Chicago, IL, USA). All bacterial counts were converted to $\log _{10} \mathrm{CFU} / \mathrm{cm}^{-2}$ for analysis and ANOVA was performed. Statistical significance was set at a $\mathrm{P}$ value of $<.05$.

\section{RESULTS}

The mean total viable count (TVCs) post skinning, post evisceration and post washing at brisket site was, $3.31 \pm 0.14,3.71 \pm 0.04$ and $3.65 \pm 0.02 \log \mathrm{CFU} / \mathrm{cm}^{2}$ for the control, whereas after treatment was $1.4 \pm 0.12,1.5 \pm 0.09$ and $1.5 \pm 0.06 \mathrm{log} \mathrm{CFU} / \mathrm{cm}^{2}$ with statistically significant difference $(\mathrm{P}<0.05)$. In shoulder site, TVCs for control carcasses were $3.03 \pm 0.15,2.73 \pm 0.02$ and $2.79 \pm 0.10 \log _{10} \mathrm{CFU} / \mathrm{cm}^{2}$ but in treatment samples were $1.3 \pm 0.09,1.2 \pm 0.11$ and $1.1 \pm 0.05$ $\mathrm{CFU} / \mathrm{cm}^{2}$ with statistically significant difference $(P<0.05)$. TVCs in neck site samples after operational points revealed mean values of $3.65 \pm 0.02$, $3.42 \pm 0.02$ and $3.72 \pm 0.02 \log _{10} \mathrm{CFU} / \mathrm{cm}^{2}$ and after treatment were, $1.7 \pm$ $0.05,1.4 \pm 0.06$ and $1.6 \pm 0.06 \log _{10} \mathrm{CFU} / \mathrm{cm}^{2}$ respectively $(P<0.05)$. In rump site, TVC in the three points of operation for control were $3.24 \pm 0.02,2.88 \pm 0.02$ and $3.18 \pm 0.03 \quad \log _{10} \mathrm{CFU} / \mathrm{cm}^{2}$, whereas after treatment $1.4 \pm 0.06,1.1 \pm 0.07$ and $1.2 \pm 0.10 \log 10 \mathrm{CFU} / \mathrm{cm}^{2}$ with 
statistically significant difference (Table 1). TVC in knives after skinning and evisceration for control samples were $3.40 \pm 0.02$ and $3.25 \pm 0.03 \log _{10} \mathrm{CFU} / \mathrm{cm}^{2}$ whereas after treatment were $1.5 \pm 0.07$ and $1.4 \pm 0.09 \log _{10} \mathrm{CFU} / \mathrm{cm}^{2}(P<0.05)$ (Table 2). Also the TVC, of the hands of the workers post skinning, post evisceration and post washing were $3.74 \pm 0.02,3.42 \pm 0.02$ and $3.71 \pm 0.02 \log _{10} \mathrm{CFU} / \mathrm{cm}^{2}$ for control samples but in treated samples were $1.6 \pm 0.11,1.2 \pm 0.39$ and $1.6 \pm 0.09 \log _{10} \mathrm{CFU} / \mathrm{cm}^{2}$ respectively $(P<0.05)$ (Table 2$)$.

Table 1: Total viable counts $\left(\log _{10} \mathrm{CFU} \mathrm{\textrm {cm } ^ { 2 }}\right)$ at different sites on carcasses, at different operational points before (Control) and after treatment

\begin{tabular}{|c|c|c|c|c|c|c|c|}
\hline \multirow{3}{*}{ Sites } & \multicolumn{6}{|c|}{ Operational points } & \multirow[t]{3}{*}{ Significance } \\
\hline & \multicolumn{3}{|c|}{ Control } & \multicolumn{3}{|c|}{ Treatment } & \\
\hline & $\begin{array}{c}\text { Post } \\
\text { skinning }\end{array}$ & $\begin{array}{c}\text { Post } \\
\text { evisceration }\end{array}$ & $\begin{array}{c}\text { Post } \\
\text { washing }\end{array}$ & $\begin{array}{c}\text { Post } \\
\text { skinning }\end{array}$ & $\begin{array}{c}\text { Post } \\
\text { evisceration }\end{array}$ & $\begin{array}{c}\text { Post } \\
\text { washing }\end{array}$ & \\
\hline Brisket & $\begin{array}{c}3.31 \\
\pm 0.14\end{array}$ & $\begin{array}{c}3.71 \\
\pm 0.04\end{array}$ & $\begin{array}{c}3.65 \\
\pm 0.02\end{array}$ & $\begin{array}{c}1.4 \\
\pm 0.12\end{array}$ & $\begin{array}{c}1.5 \\
\pm 0.09\end{array}$ & $\begin{array}{c}1.5 \\
\pm 0.06\end{array}$ & $*$ \\
\hline Shoulder & $\begin{array}{c}3.03 \\
\pm 0.15\end{array}$ & $\begin{array}{c}2.73 \\
\pm 0.02\end{array}$ & $\begin{array}{c}2.79 \\
\pm 0.10\end{array}$ & $\begin{array}{c}1.3 \\
\pm 0.09\end{array}$ & $\begin{array}{c}1.2 \\
\pm 0.11\end{array}$ & $\begin{array}{c}1.1 \\
\pm 0.05\end{array}$ & $*$ \\
\hline Neck & $\begin{array}{c}3.65 \\
\pm 0.02 \\
\end{array}$ & $\begin{array}{c}3.42 \\
\pm 0.02 \\
\end{array}$ & $\begin{array}{c}3.72 \\
\pm 0.02 \\
\end{array}$ & $\begin{array}{c}1.7 \\
\pm 0.05 \\
\end{array}$ & $\begin{array}{c}1.4 \\
\pm 0.06 \\
\end{array}$ & $\begin{array}{c}1.6 \\
\pm 0.06 \\
\end{array}$ & $*$ \\
\hline Rump & $\begin{array}{c}3.24 \\
\pm 0.02\end{array}$ & $\begin{array}{c}2.88 \\
\pm 0.02\end{array}$ & $\begin{array}{c}3.18 \\
\pm 0.03\end{array}$ & $\begin{array}{c}1.4 \\
\pm 0.06\end{array}$ & $\begin{array}{c}1.1 \\
\pm 0.07\end{array}$ & $\begin{array}{c}1.2 \\
\pm 0.10\end{array}$ & $*$ \\
\hline
\end{tabular}

- = Not detected'; $*=$ Significant at level $(P<0.05)$

Table 2: Total viable counts $\left(\log _{10} \mathrm{CFU} \mathrm{cm}^{2}\right)$ at knives and hands of the workers at different operational points before (Control) and after treatment

\begin{tabular}{|c|c|c|c|c|c|c|c|}
\hline \multirow{2}{*}{ Items } & \multicolumn{6}{|c|}{ Operational points } & Significance \\
\cline { 2 - 7 } & \multicolumn{3}{|c|}{ Control } & \multicolumn{3}{c|}{ Treatment } & \\
\cline { 2 - 7 } & $\begin{array}{c}\text { Post } \\
\text { skinning }\end{array}$ & $\begin{array}{c}\text { Post } \\
\text { evisceration }\end{array}$ & $\begin{array}{c}\text { Post } \\
\text { washing }\end{array}$ & $\begin{array}{c}\text { Post } \\
\text { skinning }\end{array}$ & $\begin{array}{c}\text { Post } \\
\text { evisceration }\end{array}$ & $\begin{array}{c}\text { Post } \\
\text { washing }\end{array}$ & \\
\hline Knives & 3.40 & $3 . .25$ & - & 1.5 & 1.4 & - & $*$ \\
& \pm 0.02 & \pm 0.03 & & \pm 0.07 & \pm 0.09 & & \\
\hline $\begin{array}{c}\text { Hands of } \\
\text { the }\end{array}$ & $\begin{array}{c}3.74 \\
\text { workers }\end{array}$ & 3.42 & 3.71 & 1.6 & 1.2 & 1.6 & $*$ \\
\pm 0.02 & \pm 0.02 & \pm 0.02 & \pm 0.11 & \pm 0.39 & \pm 0.09 & \\
\hline
\end{tabular}

- = Not detected'; * = Significant at level $(P<0.05)$ 


\section{DISCUSSION}

In this data, the total bacterial counts results were depended on cotton swabbing method, but (Dorsa 1996; Gill and Jones 2000; Ransom et al., 2002) showed that gauze swabbing and excision methods were the same bacterial enumerations on $100 \mathrm{~cm}^{2}$ area. Also Ware et al. (1999) obtain the same results by using these sampling methods in total aerobic count (TAC), faecal coliforms count (FCC) and $E$ coli count (ECC) before chilling.

The present work revealed statistically significant difference $(\mathrm{P}<0.05)$ before treatment of slaughtering operations, this in accord with the results of Gill (1998) who reported bacterial contamination of meat during butchering and skinning. Also, Ali (2007) revealed that the workers hands and the equipment were the sources of meat contamination.

The high level of bacterial viable counts after post washing of bovine carcasses in this study is in agreement with the study of Ali (2007) who recorded that the highest contamination at the point of washing on different sites of examination of bovine carcasses. Microbiological contamination on these beef carcasses occurred as result of conditions of multi-factorial complexity, which could include environmental condition (Gill et al., 1996). It is obvious that the variability in microbial counts (especially after washing) indicate the need for use of prerequisite programmes. The reduction of the microbial contamination in this study (Table 1) is in agreement with Rahkio and Korkeala (1996) who said that the enforcement of hygienic practice such as regular disinfection of working tools and worker hands is important in reducing the microbiological contamination of carcasses (Also Dixon et al., 1991; John et al., 2000) reported that reduction of bacterial contamination during slaughtering after using a degree of sanitation.

In conclusion, the elimination of contamination sources by practicing good sanitary measures will reduce the occurrence of microorganisms. Appropriate methods should be applied during slaughtering operations, using adequate water and disinfection. Such control measures should include an extensive education programs for proper hygiene and improvement of managements. Designing slaughtering lines so as to make hygienic working possible is evidently very important. 


\section{ACKNOWLEDGMENTS}

We are grateful to Sudan University of Science and Technology for their financial support of the research project.

\section{REFERENCES}

Abdalla, M.A.; Siham, E. Suliman and Alian, Y.Y.H.A. (2009a): Microbial Contamination of Sheep Carcasses at Slaughterhouse in Khartoum State. Sud. J. Vet. Sci. Anim. Husb. 48 (1\&2) 51-56.

Abdalla, M.A.; Suliman, S.E.; Ahmed, D.E. and Bakhiet, A.O. (2009b): Estimation of bacterial contamination of indigenous bovine carcasses in Khartoum (Sudan). African Journal of Microbiology Research 3(10) 882-886 Available online http://www.academicjournals.org/ajmr

Abdelsadig, M.B. (2006): Study of some Critical Control Points in ElKadaro Slaughterhouse. M.Sc. in public health. University of the Academy of Medical Science and Technology. Sudan.

Ali, A.A. (2007): Prevalence of bacterial contamination of public health concern on bovine carcasses at Khartoum state- Sudan. M.Sc. Thesis Sudan University of Science and Technology, Sudan.

Bacon, RT.; Belk, KE.; Sofos, JN.; Clayton, RP.; Reagan, JO. and Smith, GC. (2000): Microbial populations on animal hides and beef carcasses at different stages of slaughter in plants employing multiple-sequential interventions for decontamination. J. Food Prot.; 63: 1080-1086.

Biss, M.E. and Hathaway, S.C. (1995): Microbiological and visible contamination of lamb carcasses according to preslaughter presentation status: Implications for HACCP. J. Food Prot. 58:776-783.

Borch, E. and Arinder, P. (2002): Bacteriological safety issues in beef and ready-to-eat meat products, as well as control measures. Meat Science, Savoy, v. 62, n. 3, p. 381-390.

Barrow, G.I. and Feltham, R.K.A. (1993): Manual for the Identification of Medical Bacteria (3rd ed.), Cambridge University Press, Cambridge.

Dickson, J.S. and Anderson, M.E. (1991): Control of Salmonella on beef tissue surfaces in a model system by preand post-evisceration washing and sanitizing, with and without spray chilling. J. Food Prot. 54: 514Đ518. 
Dickson, J.S. and Anderson, M.E. (1992): Microbiological decontamination of food animal carcasses by washing and sanitizing systems: A Review. J. Food Prot. 55: 133Đ140.

Dixon, Z.R.; Acuff, G.R.; Lucia, L.M.; Vanderzant, C.; Morgan, J.B.; May, S.G. and Savell, J.W. (1991): Effect of degree of sanitation from slaughter through fabrication on microbiological and sensory characteristics of beef. J. Food Prot. 54: 200-207.

Dorsa, WJ.; Cutter, CN. and Siragusa, GR. (1996): Evaluation of six sampling methods for recovery of bacteria from beef carcass surfaces. Lett Appl Microbiol. 22: 39-41.

Doyle, M.P. (1991): Escherichia coli O157:H7 and its significance in food. Int. J. Food Microbiol. 12: 298-302

Elder, R.O.; Keen, J.E.; Siragusa, G.R.; Barkocy-Gallagher, G.A.; Koohmaraie, M. and Laegreid, W.L. (2000): Correlation of enterohemorrhagic Escherichia coliEscherichia coli O157 prevalence in feces, hides and carcasses of beef cattle during processing. Proc. Natl. Acad. Sci. USA 97:2999-3003. [PubMed].

Geratas, G.E.; Tazelaar, F.; Wippler, R. asnd Logtestijn, JG. (1982): Motivation and other determinants of workers, hygienic practice- an empirical investigation. Proc. $28^{\text {th }}$ Eur. Meet. Meat Res. Work. Madrid, 483-487.

Gerats, G.E.C. (1990): Werken aan kwaliteit. (Working towards quality). Ph.D. Thesis. The University of Utrecht. Communality Board for Livestock and Meat. Rijswijk. The Nederlands. 198pp.

Gill, C.O. (1998): Microbiological contamination of meat during slaughter and butchering of cattle, sheep and pigs. In: DAVIES, A.; BOARD, R. (Eds.) The Microbiology of Meat and Poultry. London: Blackie Academic and Professional, p. 118-157. [Links]

Gill, C.O.; McGinnis, J.C. and Badoni, M. (1996): Assessment of the hygienic characteristics of a beef carcass dressing process. J. Food Prot. 59: 136-140.

Gill, C.O.; Baker, L.P. and Jones, T.J. (1998): Identification of inadequately cleaned equipment used in a sheep carcassbreaking process. J. Food Prot. 62: 637-643

Gill, CO. and Jones, T. (1999): The microbiological effects of breaking operation on hanging beef carcass sides. Food Res Int.; 32: 453-459. 
Glimour, A.; Murry, K.A. and Madden, R.H. (2004): Determination of the principal points of products contamination during beef carcass dressing process in Northern Ireland. J. Food Prot. 67 (7): 1494-6.

Hancock, D.D.; Besser, T.E. and Rice, D.H. (1998): Ecology of Escherichia coliEscherichia coli O157:H7 in cattle and impact of management practices, p. 85-91. In J.B. Kaper and A.D. O'Brien (ed.), Escherichia coli O157:H7 and other Shiga toxinproducing E. coli strains. ASM Press, Washington, D.C.

Hess, E. and Lott, G. (1970): Kontamination des Fleisches wah-rend und nach der Schlachtung (contamination of meat during and after slaughter). Fleischwirt-schaft 50: 47-5.

John, M.; McEvoy, Alice MD.; James, J. and Sheridan, M.A. (2000): Contamination of beef carcasses during hide removal and use of a test bacterial decontamination system on beef hide The National Food Centre Teagasc, Dunsinea, Castleknock, Dublin 15.

Rahkio, M. and Korkeala, H. (1996): Microbiological contamination of carcasses related to hygiene practice and facilities on slaughtering lines. Acta Vet Scand.; 37(3): 219-28

Ransom, JR.; Belk, KE.; Bacon, RT.; Sofos, JN.; Scanga, JA. and Smith, GC. (2002): Comparison of sampling methods for microbiological testing of beef animal rectal/colonal feces, hides, and carcasses. J. Food Protect. 2002; 65: 621-626.

Schutz, F. (1991): Analysis of slaughtering techniques Fleischwirtchaft. 71: 306-309.

Stolle, F. and Reuter, G. (1989): The surveillance of plant hygiene at slaughterline. Berl. Munch. Tierarzl.Wschr. 102, 239-241

Tazelaar, F. (1987): The human factor in the hygiene problem analysis, problem solution, and implication, In: Smuulders FJM (ed): Elimination of Pathogenic Organisms from Meat and Poultry. Elsevier Applied Science Publl=ishers, London. P. 251-265.

Ware, LM.; Kain, ML.; Sofos, JN.; Belk, KE. and Smith, GC. (1999): Comparison of sponging and excising as sampling procedures for microbiological analysis of fresh beef-carcass tissue. J Food Prot.; 62: 1255-1259. 